\title{
Retraction Note: Urinary Cross-linked N-telopeptides of Type I Collagen Levels in Patients with Rheumatoid Arthritis
}

\author{
J. Iwamoto ${ }^{1} \cdot$ T. Takeda $^{1} \cdot$ S. Ichimura ${ }^{2}$
}

Published online: 19 November 2019

○) Springer Science+Business Media, LLC, part of Springer Nature 2019
2. Bolland MJ, Avenell A, Gamble GD, Grey A (2016) Systematic review and statistical analysis of the integrity of 33 randomized controlled trials. Neurology 87:2391-2402. https://doi. org/10.1212/WNL.0000000000003387

Publisher's Note Springer Nature remains neutral with regard to jurisdictional claims in published maps and institutional affiliations.

\section{References}

1. Iwamoto J, Takeda T, Ichimura S (2003) Urinary cross-linked $\mathrm{N}$-telopeptides of type I collagen levels in patients with rheumatoid arthritis. Calcif Tissue Int 72:491-497. https://doi. org/10.1007/s00223-002-1024-7

The original article can be found online at https://doi.org/10.1007/ s00223-002-1024-7.

J. Iwamoto

jiwamoto@sonata.plala.or.jp

1 Department of Sports Medicine, Keio University School of Medicine, Tokyo, Japan

2 Department of Orthopedic Surgery, National Defense Medical College, Saitama, Japan 